\title{
Motivations for Implementing Cleaner Production Principles: A Case Study of Saudi Plastic Manufacturers
}

\author{
Nadia A. Abdulghaffar ${ }^{1} \&$ Suzan Khaled Baatiyah ${ }^{1}$ \\ ${ }^{1}$ Faculty of Economics and Administration, King Abdulaziz University, Jeddah, Saudi Arabia \\ Correspondence: Nadia A. Abdulghaffar, Faculty of Economics and Administration, King Abdulaziz University, \\ Jeddah, Saudi Arabia. E-mail: nabdulghaffar@kau.edu.sa
}

Received: May 23, 2018

doi:10.5539/jsd.v11n5p18
Accepted: July 24, $2018 \quad$ Online Published: September 5, 2018

URL: https://doi.org/10.5539/jsd.v11n5p18

\begin{abstract}
The rapid economic, cultural and industrial development, and population growth in Saudi Arabia has created environmental challenges, threat of energy, resource crisis, and climate change. One of the contributing factors is the increasing number of manufacturers and lack of green practices. Therefore, this study aims to investigate the aspects that influence implementation of Cleaner Production Principles by Saudi Plastic Manufacturers. A conceptual model that was based on technological, environmental, and organizational theory was used to present the primary motivating factors of manufacturers in Jeddah for pollution reduction and also to the achievement of sustainable development goals according to Saudi Vision 2030. The research model provides motivations for the environmental and economic consequence of Cleaner Production Principles Implementation. This work is grounded in hypothesis; such as, regulatory and customer pressures having a positive influence on the implementation of $\mathrm{CP}$ principles in the Saudi plastic manufacturer industries. A questionnaire on the implementation of CP principles was provided to the manufacturers. 127 samples were analyzed through SPSS to investigate the relationship between the independent (CP Principles implementation) and dependent variables (motivational factors for implementation). The results have indicated that Regulatory Pressure and Customer Pressure has significant positive influences on the implementation of CP Principles for Saudi manufacturers. The quality of HR, SM support, governmental support, and environmental uncertainty have significant negative influences on the implementation of $\mathrm{CP}$ principles. The lack of previous research about $\mathrm{CP}$ implementation in KSA will make the results of this research beneficial for future researchers and practitioners.
\end{abstract}

Keywords: cleaner production, sustainable development, technological, organizational, and environmental theory, Saudi Plastic Manufacturers

\section{Introduction}

The economic situations have drasctically changed as well as scientific developments have been escalating rapidly since the beginning of the $21^{\text {st }}$ century. The world is facing environmental challenges, threats of resource and energy crisis, climate change, and environmental pollution (Pandey, 2005). Currently, the accomplishment of Sustainable Development (SD) goals cannot be ensured due to the environmental restrictions and paucity of resources. Maintaining SD would become increasingly difficult, if the manufacturers still keep their traditional ways in processes and productions, which cause the high-consumption of raw materials and high-pollution in the environment (Green, K. 1995).

The presence of negative consequences on the environment has already been discussed by recent studies, who enlightened the emission of wastes and toxic gases as profound causes. According to WCED (1987), increasing demands have been placed on ecological goods and services due to the increasing growth rate for meeting the needs of future generations. Subsequently, many countries have enacted a series of legislation to control toxic emissions and wastes, which can be addressed by the development of sustainability. A critical issue that stakeholders have been required to consider for improving organizational performance is to focus on sustainability. According to Hynes, W \& Wang, S., (2012), the controllong of environmental emissions, maintaining market competitveness and maintaining the economic growth are major concerns for achieving SD goals. One of the most profound way to excel these challenges is to accelerate the use of green environmental practices. The efficiency of input and raw materials is increased from the integration of technological, organizational, environmental, societal and economic strategies, which are termed as Cleaner Production (CP) 
principles. These aspects include endowing economic growth, minimizing or recycling generated waste, reducing waste and environmental benefits (Guimarães, 2013; Porter, 1995). According to Yusup, M \& Mahmood, W., (2015), the improvisation made in the use of raw materials is achieved through CP principles, allowing pollutant wastes and toxic emissions of resources to be decreased. In contrast, $\mathrm{CP}$ is defined as an enduring application that escalate the entire efficiency and mitigate risks to humans and the environment by means of preventive enviromental strategy accepted for different processes, services and products (UNEP, 2002, 2011).

According to Dangelico \& Pujari, (2010), CP is therefore considered as an environmental management strategy as it is relied on a socio-technical approach. The costs of conservation, enhancement to the efficiency of resource usage, advertising environmentally friendly practices and reducing the wastefulness of natural materials are ensured with the integration of CP (Yusup et al., 2015). Thereby, the industrial manufacturing sectors are supported by the government, providing every means of facilities and tools due to its attached significance to the economic development. Consequently, the Saudi industry has made significant progress. This progress displayed the growth of industrial investment and helped to attract investors (Hassan, M., 2017) which as a result increased the number of different types of manufacturers (SIDF, 2016).

The national transformation programs 2020 has been initiated with its initial planning in Vision 2030 by the Kingdom of Saudi Arabia (KSA). The collective efforts of these efforts would turn the far-reaching goals to accomplish environmental sustainability by escalating the waste management efficiency, ascertaining comprehensive recycling projects, fighting desertification and reducing all kinds of pollution. Additionally, it also contained measures to encourage the optimal use of water resources by reducing consumption and renewable water (SPA, 2016).

There are approximately 7007 manufacturers in Saudi Arabia. Furthermore, there are around 1076 manufacturers (PME, 2016) in Jeddah city. The industries emit toxic matter and wastes causing pollution of air and water. To achieve the Sustainable Development Goals, the Saudi government launched the 'Achieving Environmental Sustainability Plan' in the Saudi Vision 2030 and the 10th Saudi strategic plan goals (PME, 2016). Some of the obligations that were to be adhered to were that, the manufacturers must guarantee that its operations and processes will not cause unnecessary hazards which damage the environment or the public health. Apart from this, it also emphasized the protection of the air, water, and land from harmful pollution. Each department of every organization is responsible for guaranteeing their design and operation in compliance with this plan, and ensuring that they will not cause unnecessary hazards to the environment through implementation the green practices and CP principles in order to achieve environmental sustainability (Govindan, 2016).

The purpose of this paper is to investigate the main motivations, namely; Organizational Factors (OF) and the Environmental Factors (EF) that influence Saudi Plastic manufacturers in implementing CP principles. The contribution of this research is to increase the knowledge of CP principle's implementation in the KSA society. Furthermore, the study examines the organizational and environmental factors to implement $\mathrm{CP}$ and to achieve sustainable development goals according to 2030 Saudi vision targets.

\section{Theoretical Background}

\subsection{Cleaner Production (CP). Definition and Benefits}

Cleaner Production (CP) is an environmental management strategy that is based on a socio-technical approach (Yusup \& Mahmood, 2015). The United Nations Environmental Programme (UNEP, 2002), defines CP as "the continuous application of an integrated preventive environmental strategy applied to processes, products, and services to increase overall efficiency and reduce risks to humans and the environment" (Yusp \& Mamood, 2015). This is accomplished through improving the use of raw materials (including water and energy), which decrease pollutant wastes and the toxic emissions of resources (Dangelico \& Pujari, 2010). The implementation of $\mathrm{CP}$ has successfully provided promising benefits with a wide range of implications to the manufacturing firms, employees, and the environment (Getzner, 2002).

\subsection{Cleaner Production Requirements}

The development of SD requires the demand for the implementation of CP principles among the manufacturers and the capacity to meet that demand through the following stages:

- First, integration of $\mathrm{CP}$ principles can give economic support and enhance environmental performance by supporting and motivating industrial manufacturers (Marcotte and Weaver, 2004). 
- Second, different factors are used to evaluate the awareness and preference for improving the industrial environmental performance. Specifically, the commitment will be higher of any company leader, when external pressures are higher (Epstein, 2009).

- Third, the potential of executing eco-efficiency projects, which include access to a group of technical specialists, financing schemes and qualified consultants for $\mathrm{CP}$ integration, is achieved through the $\mathrm{CP}$ technology (Hicks \& Dietmar, 2007).

- Fourth, CP implementation in the industrial areas requires how raw emissions can be made less harmful to both humans and the environment through identifying the hazardous substances to be phased out (Cobut \& Beauregard, 2013).

- Finally, implementation of CP reduces environmental risks and liabilities, and leads to higher competitiveness. It also improves public image and gains the confidence of consumers (Hwang and Wu, 2016).

\subsection{Key Drivers of Green Practices through Implementation CP Principles}

Delmas (2004) points out the drivers that motivate organizations to implement green practices in their processes. These drivers come from pressures of external and internal stakeholders such as government, investors, customers, suppliers, community groups, and employees (Delmas \& Toffel, 2004). Additionally, it improves organizational culture; by inculcating moral values to do the right thing and to be socially responsible (Carter \& Jennings, 2002). It also appears most appropriate for explicating the effect of the drivers of green practices and how they might influence specific environmental initiatives. The following four constructs collectively measure the drivers of green practices initiatives (Hoffman, 2001):

- Regulatory measures (REG). The ability of the government to formulate and implement sound policies and regulations that encourage the implementation of green practices (Bansal and Roth, 2000).

- Competitor pressures (COMPRE). Extensive and successful firms in the industrial sector usually face high pressure from competitors and external environmental activists (Zhu and Sarkis, 2007). This leads them to work in environmental management through implementing green practices and $\mathrm{CP}$ principle initiatives to gain competitive advantage (Canning \& Hanmer-Lloyd, 2001; Carter and Ellram, 1998).

- Customer pressures (CUSTPRE). This is the pressure coming from the consumers when they are beginning to question the environmental effects of the products that they buy. In addition, they expect firms to implement the green standard in their products and process designs (Tate et al., 2010). This kind of pressure causes the organizations to be more legitimate and trustworthy to the environmental issues (Sarkis et al., 2011).

- Socio-cultural responsibility (SOCCUL). This is the ability of organizations in the industrial sectors, to use business to inspire solutions to the environmental crisis. It is an organization's obligation to society, to achieve harmony with social expectations, norms, and codes of conduct that dictate acceptable business behaviors (Jones, 1999).

As a result, organizations around the world want to paint a positive image, due to intense global competition. They are forced to consider socio-cultural responsibility in all of their processes, production, and practices by switching to environmentally friendly components to minimize environmental impact (Chin-Chun \& Keah, 2012).

\subsection{The Benefits of CP Implementation}

The integration of CP principles has given an in-depth amount of benefits to the manufacturing companies (Hicks \& Dietmar, 2007). The economic, manufacturing and environmental competency of manufacturing companies will positively have influenced by the adoption of CP principles. Number of organizations are affected by the sustainability and environmental pollution globally. The industrial sector is enforced to change their operations and tactics due to the increase in the global issues and to merge environmental concerns into their organizational responsibility (Hsu \& Tan, 2012). Thereby, devastating environmental, social and economic outcomes will be prevented through the adoption of CP principles and green practices operations (Moffatt, 2004). According to UNEP (2002), CP is based on social responsibility aspects; thereby, acknowledged as a SD tool. Implementation, development and support of $\mathrm{CP}$, pollution prevention and green strategies assist in the protection of the global environment (Maria Gavrilescu, 2004). According to UNEP (1998), CP is an enduring application of a preventive and integrated strategy, which is accepted for products, services and processes to seek the social, health, safety, environmental and economic benefits. The three dimensions of SD in a strategic manner is advanced by the Organization for Economic Co-operation and Development (OECD) by asserting following points; 
- The productive use of natural resources is optimized through productive efficiency of organizations.

- The impact of environment and nature is minimized through environmental management aspects that generate waste and emissions, enhance productive use of organizational chemicals and stimulate the management.

- By minimizing risks, people and communities can be supported by organizations to raise human development.

\subsection{The Organizational Factors}

The difference in internal resource foundations and processes is affirmatively seen among organizations that react to internal and external challenges due to such abilities. Internal organizational stakeholders, organizational resources and assets are profound organizational factors. The decision-making powers of these individuals and groups allowed them to be called stakeholders. In addition, environmental sustainability is achieved through the organizational adoption of green practices. Organizations are profoundly affected by these factors to enhance their competitive advantage (Florida, 2001). Therefore, this study develops two constructs on the basis of TOE theory. The quality of human resource, the senior management support are the organizational factors used in the study.

\subsubsection{Senior Management Support}

Technical innovation will be influenced by the extent to which a company stimulates by means of new system or technology. The acceptance and integration of technical innovation has been positively affected through the provision of motivation for technical and financial resources (Jeyaraj, 2006). The implementation of green behavior is supported by organization for the employees. In general, an active role has been played by the senior management to provide organizational support (Organizational Behavior, 2017).

$\mathrm{G} / \mathrm{CP}$ production principles require the collaboration and coordination of different departments and divisions to ensure successful implementation. Moreover, these green principles are usually initiated from the top management. The central task of senior management is to gain resources and allocate them efficiently to implement green principles in order to achieve competitive environmental advantage (Gonzalez, 2005). The organizational support will positively affect the implementation of $(\mathrm{G} / \mathrm{CP})$ production principles' practices for Plastic Saudi manufacturers and propose the following hypothesis:

H1: Organizational support has a positive influence on the implementation of CP principles in the Saudi plastic manufacturing industry.

\subsubsection{Quality of Human Resources}

In any organization, the implementation of $(\mathrm{G} / \mathrm{CP})$ production principles require qualified employees with high skills, competencies, and capabilities (Tornatzky \& Fleischer, 1990). Implementation of (G/CP) production principles is a complicated process which requires correction, significant changes and coordination in the existing operation process (Russo \& Fouts, 1997). G/CP depends on the training and development of tacit skills through the involvement of employees (Del Brio \& Junquera, 2003).

The implementation of production principles will be essentially utilized through competent learning capabilities in training programs. Furthermore, firms will motivate strongly to integrate these principles as they enhance innovative and learning capabilities of employees (Frambach \& Schillewaert, 2002). According to Christmann (2000), the strategy of environmental management is plausibly implemented with the higher innovative capacity of an organization. In certain, the implementation of production principles for saudi manufacturers will be positively affected by the current human resources quality. The following hypothesis is proposed:

H2: The quality of human resources has a positive influence on the implementation of CP principles in the Saudi plastic manufacturing industry.

\subsubsection{Environmental Factors}

The acceptable behaviors and practices are reviewed by the organization, considering the moral, cultural and legal boundaries (Scott, 1997). According to Krishnan (2004), survival capabilities, increased legality and reduced uncertainty are used to reward the employees within organization-setting. This study draws four constructs from prior studies based on the TOE theory of environmental factors which are: The regulatory pressure, customer pressure, government support and the environmental uncertainty.

\subsubsection{Regulatory Pressures}

The activities of organization are affected by the stakeholders, who usually are considered to be the regulators of the organization. The decisions made by the stakeholders are essentially characterized in addressing environmental issues (Etzion, 2007). According to Christmann, (2004), primary stakeholders are satisfied by the 
activities of the organization. Thereby, the implementation of $(\mathrm{G} / \mathrm{CP})$ production principles will be affected positively by the regulatory pressure in the context of Saudi manufacturing companies. The following hypothesis is proposed:

H3: The regulatory pressure has a positive influence on the implementation of CP principles in the Saudi plastic manufacturing industry.

\subsubsection{Customer Pressures}

The implementation of particular behaviors is ensured due to the organizational pressures. For instance, external stakeholders are the ones who exercise such pressures within the organization-setting in the pursuit of the organization (Vachon, 2009). Thereby, the steps taken by the organization towards the products, services and processes are entirely based to address the environmental issues with increase in customers' awareness (Wolf, 2011). In certain, the implementation of (G/CP) production principles will be positively affected by the customer pressure for Saudi manufacturers. The following hypothesis has been proposed:

H4: The customer's pressure has a positive influence on the implementation of CP principles in the Saudi plastic manufacturing industry.

\subsubsection{Governmental Support}

The availability of external resources allows the adoption of $\mathrm{G} / \mathrm{CP}$ principles based on the green practices. The green practices are improved by stimulating the processes, which include training programs, technical resources, and provision of financial motivation (Scupola, 2003 \& Tornatzk, 1990). In certain, the implementation of G/CP practices in any organization is influenced by the accessibility of external resources (Rothenberg \& Zyglidopoulos, 2007; Aragon-Correa \& Sharma, 2003). According to Aragon-Correa \& Sharma (2003), bank financing at lower charges, lower insurance premiums and governmental subsidies are included in the government support. The implementation of production principles is positively influenced by governmental support. Thereby, this study has expected that the implementation of green practices for Saudi plastic manufacturers will be positively affected by the governmental support and propose the following hypothesis:

H5: Governmental support has a positive influence on the implementation of CP principles in the Saudi plastic manufacturing industry.

\subsubsection{Environmental Uncertainty}

Environmental uncertainty has been observed as the environmental factors that affect an organization's decision making (Li \& Gima, 2002). It refers to the unpredictable changes in technological development, customer preferences, and competitive behavior. A manager who is facing uncertain business environments is active in creating innovative strategies compare with a manager who is working in a stable environment. High environmental uncertainty push the organizations to gather and process information frequently and rapidly to address environmental changes (Gupta \& Govindrajan, 1991). In addition, they tend to implement green practices and increase the rate of technical, environmental issues that are faced to maintain a competitive advantage (Zhu \& Weyant, 2003; Damanpour,1991; Kimberly,1981).

As implementation $(\mathrm{G} / \mathrm{CP})$ production principles can be regarded as a technical process that can improve an organization's environmental performance, green practices implementation is expected to be positively associated with environmental uncertainty. Organizations are more likely to implement green practices, to generate the capacity which improves environmental performance in uncertain environments (Aragon-Correa \& Sharma, 2003 and Rothenberg \& Zyglidopoulos, 2007). Therefore, we expect that environmental uncertainty will positively affect the implementation of $(\mathrm{G} / \mathrm{CP})$ production principles for Saudi plastic manufacturers and propose the following hypothesis:

H6: The environmental uncertainty has a positive influence on the implementation of CP principles in the Saudi plastic manufacturing industry. 


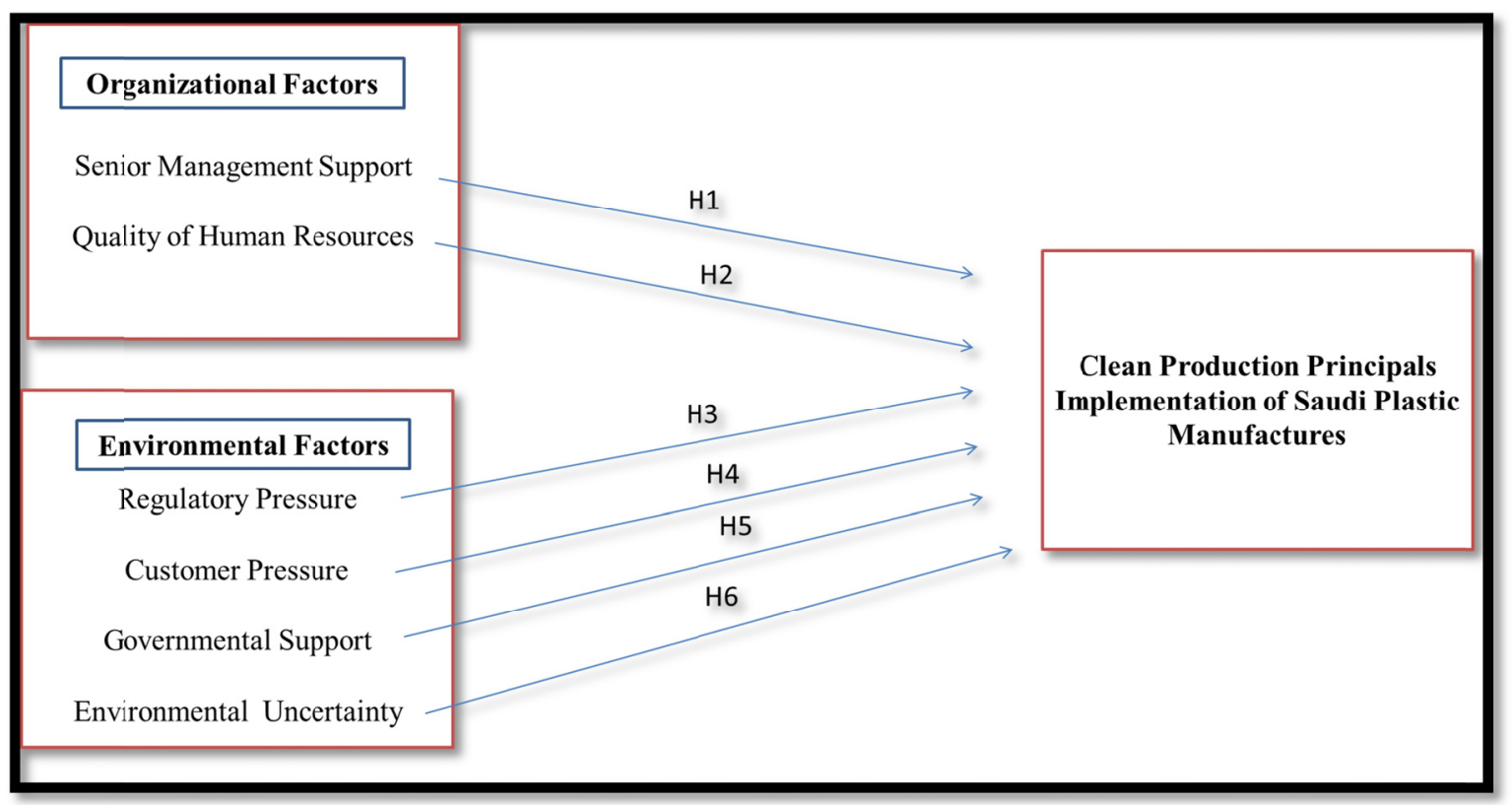

Figure 1. The Organizational and Environmental Factors influence the implementation of CP Principles

\section{Research Methodology}

The research methodology is based on appropriate steps to collect the data and to investigate the hypotheses. Moreover, the definition of the constructs, data collection procedures, the sampling strategy, and unit of analysis are described. The questionnaire comprised of closed-ended questions that limit the answers options (Sincero, 2012). The questionnaire was adopted for this study to test the research model to examine factors affecting the stakeholders in the implementation of CP principles in the Saudi Plastic Manufacturing industry. The main industrial cities in KSA are Riyadh, Jeddah, and Dammam. In this research; the plastic manufacturers in Jeddah are the sample population. Jeddah has a strategic location due to its proximity to the city center and Jeddah Islamic Port, which is the largest port in Saudi Arabia (MODON, 2017). In Jeddah, the number of existing manufacturers is 1779 (MCI, 2015). Our sample is limited to approximately 130 plastic manufacturing industries.

150 questionnaires were distributed to these manufacturer's, namely; the stakeholders and the senior managers who make the decisions to implement the environmental activities. A total of 135 questionnaires were returned. Of these respondents, eight questionnaires were excluded. So, the complete questionnaires which were usable were 127. Thus, the overall response rate is approximately $84 \%$. The study sample consisted of 127 questionnaires. The key of these respondents is summarized in the table 1. The categories shown are Gender, Education Level, Work Position, Work Experience, and Manufacturers Size. 
Table 1. Descriptive statistics of respondent's general information

\begin{tabular}{|c|c|c|c|}
\hline Variables & Category & Frequency (n) & Percentage $(\%)$ \\
\hline \multirow[t]{2}{*}{ 1. Gender } & Male & 127 & 100.0 \\
\hline & Female & 0 & 0 \\
\hline \multirow[t]{5}{*}{ 2. Education Level } & Secondary & 1 & 0.8 \\
\hline & Bachelor & 96 & 75.6 \\
\hline & Master & 14 & 11.0 \\
\hline & Doctorate & 0 & 0 \\
\hline & Other & 16 & 12.6 \\
\hline \multirow[t]{6}{*}{ 3. Work Position } & Operation Manager & 30 & 23.6 \\
\hline & Production Manager & 15 & 11.8 \\
\hline & Planning Manager & 6 & 4.7 \\
\hline & Maintenance Manager & 12 & 9.4 \\
\hline & Product Manager & 11 & 8.7 \\
\hline & Other & 53 & 41.7 \\
\hline \multirow[t]{6}{*}{ 4. Work Experience } & Less than one year & 1 & 0.8 \\
\hline & $1-3$ years & 30 & 23.6 \\
\hline & 3-5 Years & 4 & 3.1 \\
\hline & 5-7 Years & 36 & 28.3 \\
\hline & 7-10 Years & 24 & 18.9 \\
\hline & Other & 32 & 25.2 \\
\hline \multirow[t]{5}{*}{ 5. Manufacturer's Size } & Less than 100 Employees & 3 & 2.4 \\
\hline & 100 - 1,000 Employees & 77 & 60.6 \\
\hline & 1,000 - 10,000 Employees & 46 & 36.2 \\
\hline & 10,000 - 50,000 Employees & 1 & 0.8 \\
\hline & More than 50,000 Employees & 0 & 0 \\
\hline
\end{tabular}

The dependent variable has been the CP principles' implementation, while the two organizational factors and four environmental factors are the independent variables. Table (2) presents the Cronbach's Alpha values which is used to check the reliability and validity of the questionnaire construct and items; the assessment was calculated using SPSS software (Version 21) to analyze the collected data. The majority of constructs show satisfying results for Cronbach's alpha and are close to 1 (Philippsen, 2015). Cronbach's alpha coefficient higher than or equal to 0.70 was taken as an acceptable standard for reliability of the scale (Al-Rubaish. et al, 2010. The observed alpha coefficients ranged from (0.728) to (0.959), indicating an exceptionally excellent to high reliability. This implies that the sampling results are reliable. 
Table 2. Cronbach's Alpha $(\alpha)$ reliability test for the study

\begin{tabular}{|c|c|c|c|}
\hline Construct & $\begin{array}{l}\text { Cronbach's } \\
\text { Alpha }\end{array}$ & $\begin{array}{l}\text { Number of } \\
\text { items }\end{array}$ & $\begin{array}{l}\text { Number of } \\
\text { cases }\end{array}$ \\
\hline 1. The implementation of the CP / GRE principles. & 0.737 & 5 & 127 \\
\hline $\begin{array}{l}\text { 2. The senior management support in the implementation } \\
\text { of CP / GRE practices. }\end{array}$ & 0.959 & 13 & 127 \\
\hline $\begin{array}{l}\text { 3. The quality of the human element in accepting } \mathrm{CP} / \\
\text { GRE production practices. }\end{array}$ & 0.776 & 6 & 127 \\
\hline $\begin{array}{l}\text { 4. The regulatory pressures towards implementing } \mathrm{CP} / \\
\text { GRE practices. }\end{array}$ & 0.872 & 3 & 127 \\
\hline $\begin{array}{l}\text { 5. The customer pressure towards implementing CP / } \\
\text { GRE practices. }\end{array}$ & 0.866 & 2 & 127 \\
\hline $\begin{array}{l}\text { 6. The government support for implementing CP / GRE } \\
\text { practices. }\end{array}$ & 0.728 & 3 & 127 \\
\hline $\begin{array}{l}\text { 7. The environmental changes (uncertain) towards the } \\
\text { implementation of CP / GRE practices. }\end{array}$ & 0.817 & 4 & 127 \\
\hline
\end{tabular}

Table (2) has shown that SM support is essential in advancing CP initiatives adoption; it has been shown to have an excellent internal consistency with a Cronbach alpha of 0.959 (well above the recommended level of 0.70 ). Subsequently, the quality of HR has become a key business strategy for organizations where Human Resource Departments play an active part in going green practices. It has shown acceptable internal consistency reliability, with Cronbach 's alpha coefficients of 0.776 . The regulatory pressures are associated with the likelihood of companies concern with the environmental policies and activities while the government support with agreed to general principles and priority encourages areas which will guide implementation of the green practices. Both have a good consistency $(\alpha>0.8)$. Finally, the environmental uncertainty lacks factual or competent information concerning the internal and external environmental issues for the organization. This has acceptable internal consistency reliability with a Cronbach's alpha of 0.817 .

\section{Results}

The SM support and quality of HR were used to capture the organizational context. The SM support was measured by the degree to which the implementation of $\mathrm{CP}$ could increase environmental and economic performance (Rogers, 2003). In table 3, the correlation of SM support with implementation is $(r=0.160)$, which suggests very weak positive correlation (higher than 0 ). The correlation of quality of HR with the implementation is $(r=0.076)$, which displays very weak positive correlation. Since $(0.160$ and 0.076$)$ isn't close to 1 , this implies that the correlation between SM support, quality of $\mathrm{HR}$ with $\mathrm{G} / \mathrm{CP}$ implementation is weak.

The correlation of customers' pressures with implementation is $\left(\mathrm{r}=-0.200^{*}\right)$. Which is based on 127 pairs of numbers $(\mathrm{N})$ and implies (r) is a weak negative correlation, while the regulatory pressure, governmental support and environmental uncertainty have a very weak correlation with the implementation. The correlation between the SM support, and both quality of HR is a weak positive correlation. While the correlation between the regulatory pressure and customers pressure is a positive weak correlation with $\left(\mathrm{r}=0.244^{* *}\right)$. Moreover, the government support has a very weak negative correlation with both regulatory and customers pressure. The environmental uncertainty has a positive weak correlation with government support $\left(\mathrm{r}=0.318^{* *}\right)$. 
Table 3. Correlation analysis

\begin{tabular}{|c|c|c|c|c|c|c|c|c|}
\hline \multicolumn{9}{|c|}{ Description Correlations } \\
\hline Variables & Means & 1 & 2 & 3 & 4 & 5 & 6 & 7 \\
\hline 1. Implementation & 4.03 & 1 & & & & & & \\
\hline 2.SM support & 4.21 & 0.160 & 1 & & & & & \\
\hline 3. Quality of the HR & 3.71 & 0.079 & $.382 * *$ & 1 & & & & \\
\hline 4. Regulatory Pressure & 4.32 & $0.187^{*}$ & $0.359 * *$ & 0.099 & 1 & & & \\
\hline 5. Customers Pressure & 3.74 & $-0.200^{*}$ & 0.041 & 0.073 & $0.244 * *$ & 1 & & \\
\hline 6. Government Support & 2.64 & 0.125 & 0.046 & $0.206^{*}$ & -0.017 & -0.025 & 1 & \\
\hline 7. Environmental Uncertainty & 3.38 & 0.158 & -0.004 & 0.054 & 0.048 & 0.020 & $0.318 * *$ & 1 \\
\hline \multicolumn{9}{|c|}{ **. Correlation is significant at the 0.01 level (2-tailed). } \\
\hline *. Correlation is significant at & he $0.05 \mathrm{le}$ & vel (2-tail & & & & & & \\
\hline
\end{tabular}

\subsection{Standardized Regression Results}

The next step after testing measurement model is to ensure that it has acceptable psychometric properties and subsequently test the structural model. Regression analysis is used in the study, to verify whether the proposed organizational, and environmental factors will affect the implementation of CP for Saudi Plastic Manufacturers. It takes the ten determinant factors as independent variables and the implementation of $\mathrm{CP}$ as the dependent variable. The structural model can be tested by examining $\mathrm{R}$ square $\left(\boldsymbol{R}^{\mathbf{2}}\right)$ and the structural path coefficient beta weight (B) which express the relative importance of independent variables (Logistic Regression).

Table 4. Standardized regression results of Saudi Plastic Manufactures CP implementation 4 represents the result of the structural model and the hypotheses path, significance of the path coefficient and the influence of the structural model and the hypotheses path. In addition, it represents the significance of the path coefficient and the influence of the independent variable.

Table 4. Standardized regression results of Saudi Plastic Manufactures CP implementation

\begin{tabular}{lcccc}
\hline \multicolumn{1}{c}{ Dependent Variables: CP principles' Implementation $(\mathrm{N}=127)$} & & & \\
\hline \multicolumn{1}{c}{ Predictors } & Standardized Coefficient $(\beta)$ & $\mathrm{t}$ & R-Square & Sig \\
\hline H1 Senior Management support & Organizational Factors & & & \\
H2 Quality of the human resources & 0.16 & 1.81 & 0.026 & 0.073 \\
\hline \multicolumn{7}{c}{ Environmental Factors } & & 0.886 & 0.006 & 0.377 \\
\hline H3 Regulatory Pressure & $0.187^{*}$ & $2.129^{*}$ & 0.035 & 0.035 \\
H4 Customer Pressure & $-0.2^{*}$ & $-2.283^{*}$ & 0.04 & 0.024 \\
H5 Governmental Support & 0.125 & 1.413 & 0.016 & 0.16 \\
H6 Environmental Uncertainty & $0.158+$ & $1.787+$ & 0.025 & 0.076 \\
\hline
\end{tabular}

$+\mathrm{p}<0.1, * \mathrm{p}<0.05, * * \mathrm{p}<0.01$

The standardized path coefficient indicates the strength of the relationships between the dependent and independent variables (Field \& Miles, 2012).

Path coefficient and R-Square indicates how well the model is performing. Table (4) illustrates P-Value for each hypothesis is less than 0.01 . Thus; there is statistically significant motivation to implement $\mathrm{CP}$, and the table showed the standardized result of the regression analysis. The result reveals that the hypotheses $\mathrm{H} 3$ and $\mathrm{H} 4$ are supported; all the other hypotheses aren't supported. 


\section{Discussion}

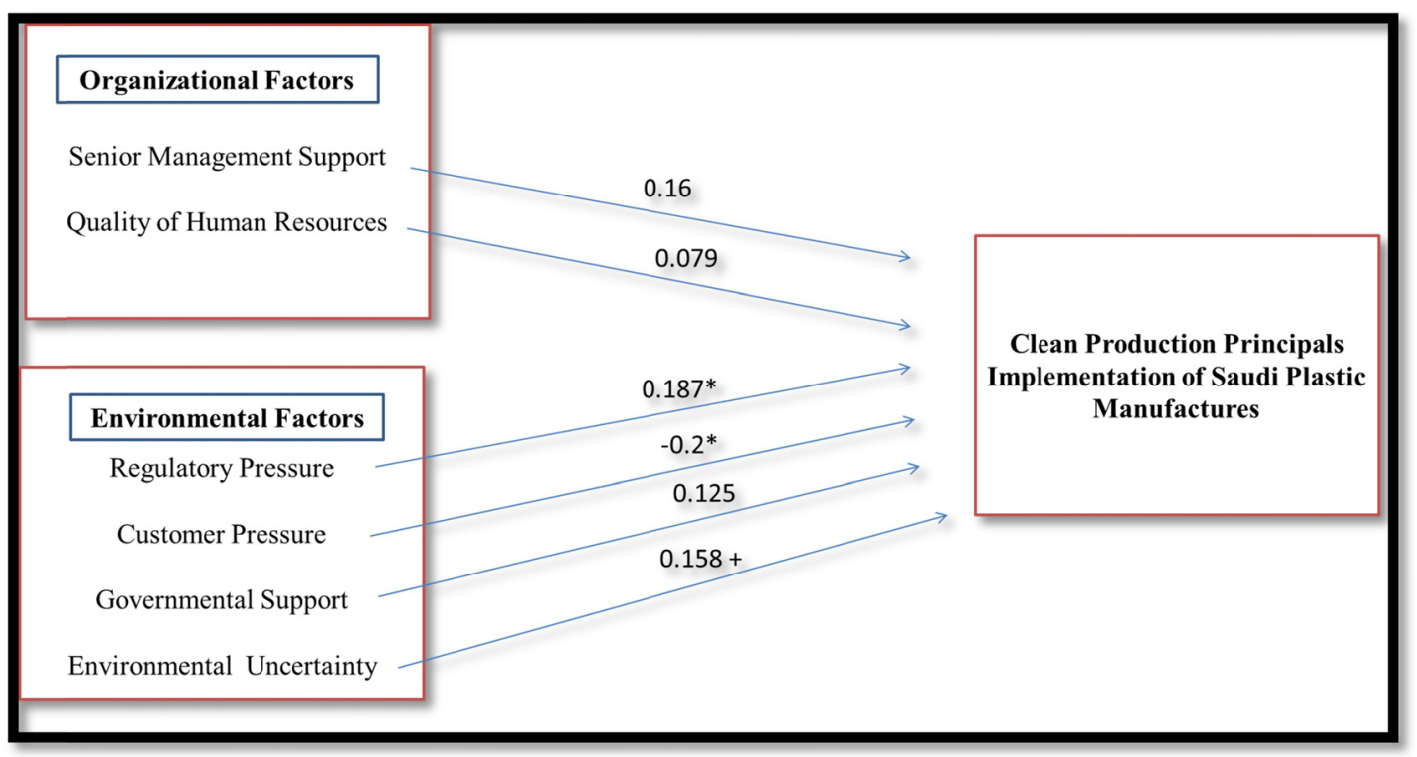

Figure 2. The Investigating of the Motivation Factors to Implementation CP principles Structural Model

In order to verify whether the proposed technological factors will affect the implementation of CP principles for Saudi plastic manufacturers, the regression analysis is used in the study which takes the determinant factors as independent variables and the implementation of $\mathrm{CP}$ as the dependent variable. In the present regression analysis, the regression assumption of linearity, normality, independent of residuals and the absence of multilinearity are all satisfied. Figure (2) shows the standardized result of the regression analysis. The result revealed that the hypothesis $\mathrm{H} 3$ and $\mathrm{H} 4$ are supported and all the other hypotheses are not supported.

\subsection{Influences of Organizational Factors}

Based on the result of the questionnaire, the hypotheses are related to the organizational factors

H1: Senior Management support has a positive influence on the implementation of CP principles in the Saudi plastic manufacturing industry.

Organizational factors are essential in environmental management and influence the implementation the CP principles (Zhu et al. , 2008). The Senior managers and employees need to have a shared vision and a shared understanding of the organization's mission. The strategies can translate into organizational goals and objectives (Yrk, 2010). If one of the missions of the organization is to protect the natural environment, it is important to involve employees by implementing the appropriate HRM practices at different strategic levels which contribute to the SD (Molina-Azorın, 2009). In this study of Saudi Plastic Manufacturers, we found that Senior Management support does not influence the implementation of CP. Here, the hypotheses related to organizational factors. $\mathrm{H} 4$ is not supported, the influencing effect is not statistically significant $(b=0.160, t=1.810, p>0.01)$, which suggest that SM support will not affect $\mathrm{CP}$ implementation behavior for plastic manufacturers. The top management support is not essential in advancing CP implementation unless the organization's resource supports leader's attitudes toward environmental issues (Tornatzky \& Fleischer, 1990).

H2: The quality of human resources has a positive influence on the implementation of CP principles in the Saudi plastic manufacturing industry.

The hypotheses $\mathrm{H} 2$ is not supported and the influencing effect is not statistically significant $(b=0.079, t=0.886$, $\mathrm{p}>0.01$ ), which suggests that the use of CP principles may add complexity to manufacturers processes and require learning, capabilities and training programs. Subsequently, it is essential to provide education and training for employees in managing environmental issues and dealing with these issues in active ways (Wolf \& Seuring, 2010). By improving organizational learning capabilities; plastic manufacturers should recruit qualified employees, provide educating programs, and build knowledge management systems. 


\subsection{Influences of Environmental Factors}

The hypotheses related to the environmental factors based on the results of the questionnaire:

H3: The regulatory pressure has a positive influence on the implementation of CP principles in the Saudi plastic manufacturing industry.

H4: The customer's pressure has a positive influence on the implementation of CP principles in the Saudi plastic manufacturing industry.

H5: The governmental support has a positive influence on the implementation of CP principles in the Saudi plastic manufacturing industry.

H6: The environmental uncertainty has a positive influence on the implementation of CP principles in the Saudi plastic manufacturing industry.

Regarding the influences of environmental factors, only hypotheses H3 ( $b=0.187, t=2.129, p<0.01)$, about regulatory pressure, and $\mathrm{H} 4(\mathrm{~b}=-0.200, \mathrm{t}=-2.283, \mathrm{p}<0.01)$, about customer pressure, are supported. However, the hypotheses H5 ( $b=0.125, t=1.413, p>0.01)$, about governmental support, and H6 $(b=0.158, t=1.787, p>0.01)$, about environmental uncertainty is not supported.

The supported hypotheses $\mathrm{H} 3$, and $\mathrm{H} 4$ emphasized that the regulatory and customer pressures affect the implementation of CP principles' in plastic manufacturing industry. CP is driven by both regulatory push and pull effect, both regulatory, and customer pressure will affect the implementation of $\mathrm{CP}$ principles and green practice implementation behavior. In manufacturing sectors, which address that customers are important stakeholders for organizations; their pressure significantly affects the organization's environmental activities (Etzioni, 2007; Lin \& Ho, 2011).

Regarding the research hypotheses $\mathrm{H} 5$, the regression shows that governmental pressure has a non-significant result. However, the influencing effect is not statistically significant $(b=0.125, t=1.413, p>0.01)$. Although the Saudi government provides financial and technical support for implementing CP, they do not influence the CP implementation (Lee, 2008), since most of the Saudi manufacturers suffer from the lack of financial and technical resources and qualified professionals.

Saudi Governmental support is essential in environmental management through developing environmental policies that can offer an economic incentive, reduce long-term uncertainties, and provide the required resources for the manufacturers to implement CP (Lee, 2008).

Regarding the research hypotheses $\mathrm{H} 6$, the regression shows that the environmental uncertainty has a present non-significant result. The influencing effect is not statistically significant $(b=0.158, t=1.787, p>0.01)$. Based on the changes, the environmental uncertainty was tested for evaluating the changes specified in the development of new technologies, innovative abilities and customers' requirement (Zhu \& Weyant, 2003). Thereby, saudi plastic manufacturers put additional resources to improvve their primary business activities as compared to improve their environmental performance when they possess a high extent of uncertainty in business environment. Investments in $\mathrm{CP}$ will be delayed until other productive process changes are made.

\subsection{In General}

Hypotheses (H3 and H4) are supported, which suggest that Regulatory Pressure, and Customer Pressure, will significantly affect $\mathrm{CP}$ principles' implementation for Saudi plastic manufacturers. Note the Regulatory Pressure ( $\beta=0.187)$, and Customer Pressure $(\beta=-0.200)$. While, $(\mathrm{H} 1, \mathrm{H} 2, \mathrm{H} 5$, and H6) aren't supported, which implies that the quality of HR, SM support, governmental support and environmental uncertainty will not significantly affect CP principles' implementation for Saudi Plastic Manufacturers. Note the quality of the human resources $(\beta=0.079)$, Senior Management support $(\beta=0.16)$, Governmental Support $(\beta=0.125)$, and Environmental Uncertainty $(\beta=0.158)$.

The following section provides discussion on the results of the study, as follow:

This study conducts a questionnaire on the motivations factors affecting $\mathrm{CP}$ implementation for plastic manufacturers in KSA. The determinant motivating factors have been classified into Organizational, and Environmental factors. The research findings reveal that regulatory and Customer Pressures towards the implementation of $\mathrm{CP}$ have significant positive influences on $\mathrm{CP}$ implementation for Plastic Manufacturers. While, quality of HR, SM Support, Governmental Support and Environmental Uncertainty exhibit significant negative influences which are related to:

H1: Senior Management support has a negative influence on the implementation of CP principles in the Saudi 


\section{plastic manufacturing industry}

H2: The quality of human resource has a negative influence on the implementation of CP principles in the Saudi plastic manufacturing industry.

Taking the above hypotheses into consideration, the managers of the manufacturers themselves need to sustain more organizational support, to implement the green practices in their manufacturing industries. Besides, encouraging their employees' to implement green practices, learning, training programs and the availability of resources are relevant for the implementation of CP. While making organizational green resources readily available for their employees, improving their quality of HR and accumulating environmental knowledge is equally essential.

H5: The governmental support has a negative influence on the implementation of CP principles in the Saudi plastic manufacturing industry.

Second, from the negative influence of Government Support to implement CP Principles' in manufacturing industry, it can be safely suggested that to guarantee that the manufactures will implement the CP in their processes and, products, the Saudi government has to provide them with more of the financial, technical and educational resources to implement $\mathrm{CP}$ practices.

H6: The environmental uncertainty has a negative influence on the implementation of CP principles in the Saudi plastic manufacturing industry.

It has been stated that high degree of uncertainty is possessed by Saudi plastic manufacturers in their business environment when environmental uncertainty is negatively influenced toward CP principles. In certain, primary business activities are improved by utilizing additional resources as compared to improve environmental performance. Subsequently, until additional productive process changes are made, investments in green practices and processes will be delayed. The Saudi manufacturers in highly uncertain environments may allocate fewer resources to environmental initiatives, indicating negative relationship with $\mathrm{CP}$ implementation (Del Brio \& Junquera, 2007). Lin \& Ho (2011) in their study also suggested the negative relationship between environmental uncertainty and green adoption practices in Chinese logistics companies. When the logistic companies perceive a high degree of uncertainty in their business environment, they put more resources in improving their primary business activities rather than in improving their environmental performance. This research has certain limitations; firstly, there are lack of previous studies in CP principles in KSA. Moreover, the research findings obtained from data collected in KSA (Jeddah) may be limited in their generalizability. Different cities in KSA may lead to conclusions that are different from the present study. Other studies can use the proposed model in other cities in KSA. Similarly, the unavailability of objective measurements of CP principles' implementation for the manufacturers in KSA resulted in reliance on subjective responses of the samples. This study may suffer from respondent bias. Participants may modify their responses to be socially acceptable or rational.

\section{Conclusion}

This study highlights the influence of the motivational factors towards the implementation of $\mathrm{CP}$ principles, through the questionnaire distributed among the Saudi plastic manufacturers. The results have shown that Regulatory Pressure and Customer Pressure are the main motivating factors towards the implementation of CP in Saudi manufacturers. While, the quality of HR, SM Support, Governmental Support, and environmental uncertainty do not significantly support the implementation of CP in the Saudi manufacturing industry. In KSA, the rules and regulations from the Ministry of Commerce and Industry have still been weak and unclear. Besides, the lack of support from the Saudi government and the limited knowledge from the stakeholders about both environmental and financial benefits from the implementation of environmental principles make them the neglected investment in the environmental practices. The ministry of Commerce and Industry should formulate environmentally strong rules and regulations for the manufacturers to improve their operations and processes in favor of greener practices. Additionally, there must be imposition of taxes for the pollution that the manufacturers cause. The lack of previous research about CP implementation in KSA would make the results useful for other researchers to study variable and data collection in the same subject on more extensive samples.

\section{Acknowledgment}

The authors are very thankful to all the associated personnel in any reference that contributed in/for the purpose of this research. 


\section{References}

Agon-Correa, J. A., \& Sharma, S. (2003). A contingent resource-based view of proactive corporate environmental strategy. Acad. Manage. Rev., 28(1), 71-88. https://doi.org/10.5465/amr.2003.8925233

Al-Rubaish, A., Abdul Rahim, S., Hassan A., Al Ali, A., Mokabel, F Hegazy, M., \& Wosornu, L. (2010). Developing questionnaires for students' evaluation of individual faculty's teaching skills: A Saudi Arabian pilot study. Journal of Family and \& Community Medicine, 17(2), 91-95. https://doi.org/10.4103/1319-1683.71991

Bansal, P., \& Roth, K. (2000). Why companies go green: a model of ecological responsiveness. Academy of Management Journal, 43(4), 717-736.

Canning, L., \& Hanmer-Lloyd, S. (2001). Managing the environmental adaptation process in supplier-customer relationships. Business Strategy and the Environment, 10, 225-237. https://doi.org/10.1002/bse.291

Carter, C. R., Ellram, L. M., \& Ready, K. J. (1998). Environmental purchasing: benchmarking our German counterparts. International Journal of Purchasing \& Materials Management, 34(4), 28-38. https://doi.org/10.1111/j.1745-493X.1998.tb00299.x

Changing Production Patterns: Learning from the Experiences of National Cleanerer Production Centres, UNEP Division of Technology, Industry, and Economics. (2002).

Christmann, P. (2000). Effects of "best practices" of environmental management on cost advantage: the role of complementary assets. Acad. Manage. J., 43(4), 663-680.

Christmann, P. (2004). Multinational Companies and the Natural Environment: Determinants of Global Environmental Policy Standardization. Academy of Management Journal, 47(5), 747-760. https://doi.org/10.2307/20159616

Cobut, A., Beauregard, R., \& Blanchet, P. (2013). Using life cycle is thinking to analyze environmental labeling: the case of appearance wood products. The International Journal of Life Cycle Assessment assessment, $18(3), 722-742$.

Damanpour, F. (1991). Organizational innovation: a meta-analysis of effects of determinants and moderators. Acad. Manage. J., 34(3), 555-590.

Dangelico, R. M., \& Pujari, D. (2010). Mainstreaming green product innovation: Why and how companies integrate environmental sustainability. Journal of business ethics, 95(3), 471-486. https://doi.org/10.1007/s10551-010-0434-0

Del Brio, J. A., \& Junquera, B. (2003). A review of the literature on environmental innovation management in SMEs: implications for public policies. Technol., 23(12), 939-948. https://doi.org/10.1007/s10551-010-0434-0

Del Brio, J., Ferna'ndez, E., \& Junquera, B. (2007). Management and employee involvement in achieving an environmental action-based competitive advantage: An empirical study. International Journal of Human Resource Management, 18(4), 491-522. https://doi.org/10.1080/09585190601178687

Delmas, M. A., \& Toffel, M. W. (2004). Stakeholders and environmental management practices: an institutional framework. Business Strategy and the Environment, 13(4), 209-222. https://doi.org/10.1002/bse.409

Economywatch. (2010). Industrial Sector | Economy Watch. Retrieved December 28, 2017, from http://www.economywatch.com/world-industries/industrial-sector/

Epstein, M. (2009). Making Sustainability Work: Best Practices in Managing and Measuring Corporate Social, Environmental, and Economic Impacts. Berrett-Koehler Publishers.

Etzion, D. (2007). Research on organizations and the natural environment, 1992-present: A review. J. Manage., 33(4), 637-664. Retrieved December 17, 2017, from http://journals.sagepub.com/doi/pdf/10.1177/0149206307302553

Field, A., \& Miles, J. (2012). Discovering Statistics Using SPSS (3rd ed.).

Florida, R., Atlas, M., \& Cline, M. (2001). What makes companies green? Organizational and geographic factors in the adoption of environmental practices. Econo. Geogr., 77, 209-224. https://doi.org/10.2307/3594072

Frambach, R., \& Schillewaert, N. (2002). Organizational innovation adoption: A multi-level framework of determinants and opportunities for future research. Journal of Business Research, 55(2), 163-176. https://doi.org/10.1016/S0148-2963(00)00152-1 
Gavrilescu, M. (2004). Cleaner production as a tool for sustainable development. Environmental Engineering and Management Journal, 3(1), 45-70. Retrieved November 23, 2017, from https://www.researchgate.net/publication/284561777_Cleanerer_production_as_a_tool_for_sustainable_dev elopment

Getzner, M. (2002). The quantitative and qualitative impacts of cleaner technologies on employment. Journal of Cleanerer Production, 10(4), 305-319. https://doi.org/10.1016/S0959-6526(01)00042-7

Gonzalez. (2005). Analysing the factors influencing cleaner technology adoption: a study of the Spanish pulp and paper industry. Bus. Strategy. Environ., 14(1), 20-37.

Govindan, K., Shankar, M., \& Kannan, D. (2016). Application of fuzzy analytic network process for barrier evaluation in automotive parts remanufacturing towards cleaner production-a study in an Indian scenario. $J$. Cleaner. Prod., 114, 199-213. https://doi.org/10.1016/j.jclepro.2015.06.092

Green, K., Morton, B., \& New, S. (1995). Environmental impact of purchasing in organizations. In: Paper Presented at the Fourth Greening of Industry Conference, Toronto in November.

Gupta, A. K., \& Govindrajan, V. (1991). Knowledge flows and the structure of control within multinational corporations. Acad. Manage. Rev., 16(4), 768-792. https://doi.org/10.5465/amr.1991.4279628

Hassan, M. F. (2017). Evaluate the Corporate Profitability in the Light of the Efficiency of Working Capital Management: A Study of Petrochemical Industry Sector- KSA. Global Journal of Contemporary Research in Accounting, Auditing and Business Ethics (GJCRA), 3(1), 488.

Hicks, C., \& Dietmar, R. (2007). Improving cleanerer production through the application of environmental management tools in China. Journal of Cleaner Production, 15(5), 395-408. https://doi.org/10.1016/j.jclepro.2005.11.008

Hoffman, A. J. (2001). Linking organizational and field-level analysis: the diffusion of corporate environmental practice. Organization and Environment, 14, 133-156. https://doi.org/10.1177/1086026601142001

Hsu, C.-C., \& Tan, K. C. (2012). Supply chain drivers that foster the development of green initiatives in an emerging economy. International Journal of Operations \& Production Management, 33(6), 656-688. https://doi.org/10.1108/IJOPM-10-2011-0401

Hwang, B., Huang, C., \& Wu, C. (2016). A TOE Approach to Establish a Green Supply Chain Adoption Decision Model in the Semiconductor Industry. Sustainability, 8, 168. https://doi.org/10.3390/su8020168

Hynes, W., \& Wang, S. (2012). The Green Growth and Developing Countries. A summary for policymakers. OECD (The Organization for Economic Co-operation and Development).

Jeyaraj, A., \& Rottman, J. W. (2006). A review of the predictors, linkages, and biases in IT innovation adoption research. J. Inform. Technol., 21(1), 1-23. https://doi.org/10.1057/palgrave.jit.2000056

Jones, M. T. (1999). The institutional determinants of social responsibility. Journal of Business Ethics, 20(2), 163-179. https://doi.org/10.1023/A:1005871021412

Kimberly, J. R., \& Evanisko, M. J. (1981). Organizational innovation: the influence of individual, organizational, and contextual factors on hospital adoption of technological and administrative innovations. Acad. Manage. J., 24(4), 689-713.

Krishnan, R. A., Joshi, S., \& Krishnan, H. (2004). The influence of mergers on firm's product-mix strategies. Strategy Manag. J., 25, 587-611. https://doi.org/10.1002/smj.410

Lee, S.-Y. (2008). Drivers for the participation of small and medium-sized suppliers in green supply chain initiatives. Supply Chain Manag. An Int. J., 13, 185-198.

Lin, \& Ho. (2008). An empirical study on logistics service providers' intention to adopt green innovations. Journal of Technology Management \& Innovation, 3(1).

Lin, H.-F., \& Lin, S.-M. (2008). Determinants of E-business diffusion: A test of the technology diffusion perspective. Technovation, 28, 135-145. https://doi.org/10.1016/j.technovation.2007.10.003

Marcotte, B., \& Weaver. (2004). Using Cleanerer Production to Promote Industrial Efficiency in Developing Countries. $\quad$ Retrieved November $14, \quad 2017, \quad$ from http://www.portofentry.com/site/root/resources/analysis/2225.html 
MCI. Ministry of Commerce and Industry. (2015). Industry in KSA: Persistent Renaissance. Retrieved December 27, 2017, 2017 , $\% 20$ in $\% 20$ the $\% 2$

https://mci.gov.sa/en/Agencies/IndustrialAffairs/Documents/Industry $\% 20$ in $\% 20$ the $\% 2$

MODON. (2017). Jeddah 1st. Industrial City - Modon. Retrieved December 18, 2017, from https://www.modon.gov.sa/en/m/pages/industrialcity.aspx?itemid=18

Moffatt, I. (2004). Global warming: scientific modeling and its relationship to the economic dimensions of policy. In A. D. Owen, \& N. Hanley (Eds.), The Economics of Climate Change (Chapter 2, pp. 6-34). Routledge, London.

Molina-Azorín, J. F., Claver-Corte's, E., Pereira-Moliner, J., \& Tarí, J. J. (2009). Environmental practices and firm performance: An empirical analysis in the Spanish hotel industry. Journal of Cleaner Production, $17(5), 516-524$.

OECD. (2017). Organization for Economic Co-operation and Development. Retrieved October, 31, 2017, from http://www.oecd.org/env/outreach/eapgreen-resource-efficient-and-cleanerer-production.htm

Organizational Behavior. (2017). Essayswriters.com. Retrieved December 17, 2017, from https://essayswriters.com/essays/Analysis/organizational-behavior.html

Pandey, R. (2005). Estimating sectoral and geographical industrial pollution Inventories in India: implications for using effluent charge versus regulation. J. Dev. Stud., 41, 33-61. https://doi.org/10.1080/0022038042000276563

Philippsen, Y. (2015). Factors influencing student's intention to recycle. Retrieved October 17, 2017, from http://essay.utwente.n1/66693/1/Philippsen_MA_BMS.pdf

PME, The General Authority of meteorology and environment protection. (2016). Retrieved November 21, 2017, from https://www.pme.gov.sa/En/PAandSD/EnvironmentProtection/Pages/default.aspx

PME. (2017). The General Authority for Meteorology and Environmental Protection. Environmental Permits Air Quality. Retrieved October 14, 2017, from https://www.pme.gov.sa/En/pages/default.aspx

Rogers, E. M. (2003). Diffusion of Innovations (3rd ed.). Simon and Schuster: New York, NY, USA, 1983.

Rothenberg, S., \& Zyglidopoulos, S. C. (2007). Determinants of environmental innovation adoption in the printing industry: the importance of task environment. Bus. Strategy. Environ., 16(1), 39-49. https://doi.org/10.1002/bse.441

Russo, M. V., \& Fouts, P. A. (1997). A resource-based perspective on corporate environmental performance and profitability. Acad. Manage. J., 40(3), 534-559.

Scott, W. R. Institutions, and Organizations. (1997). Sage: Thousand Oaks, CA, USA, 1995; Volume 2.92.

Scupola, A. (2003). The adoption of internet commerce by SMEs in the South of Italy: an environmental, technological and organizational perspective. Journal of Global Information Technology Management, 6(1), 52-71. https://doi.org/10.1080/1097198X.2003.10856343

SIDF, Saudi Industrial Development Fund. (2016). Retrieved November 21, 2017, from http://www.sidf.gov.sa/en/IndustryinSaudiArabia/Pages/IndustrialDevelopmentinSaudiArabia.aspx

SIDF. Saudi Industrial Development Fund, Industrial Development in Saudi Arabia. Retrieved from http://www.sidf.gov.sa/en/IndustryinSaudiArabia/Pages/IndustrialDevelopmentinSaudiArabia.aspx

SPA, Saudi Press Agency. (2016). Saudi vision 2030. Retrieved November 21, 2017, from http://www.spa.gov.sa/galupload/ads/Saudi_Vision2030_EN.pdf

Tate, W. L., Ellram, L. M., \& Kirchoff, J. F. (2010). Corporate social responsibility reports: a thematic analysis related to supply chain management. Journal of Supply chain management, 46(1), 19-44. https://doi.org/10.1111/j.1745-493X.2009.03184.x

Tornatzky, L. G., \& Fleischer, M. (1990). The Process of Technological Innovation. Lexington, MA: Lexington Books.

UNEP, United National Environment Programme. (2002a). Retrieved November 21, 2017, from http://www.unep.fr/scp/cp/

UNEP, United Nations Environment Programme. (2002b). Changing Production Patterns: Learning from the Experience of National Cleanerer Production Centres. Retrieved December 23, 2017, from http://www.uneptie.org/shared/publications/pdf/3024-ProductionPatterns.pdf 
UNEP. (2002). Changing Production Patterns: Learning from the Experience of National Cleanerer Production Centers. United Nations Environment Program(UNEP), Division of Technology, Industry, and Economics (DTIE).

UNIDO. (2011). UNIDO green industry initiative for sustainable industrial development. Retrieved November 21 2017 ,

from http://www.greenindustryplatform.org/wp-content/uploads/2013/05/Green-Industry-Initiative-for-Sustainab le-Industrial-Development.pdf

Vachon, S., Halley, A., \& Beaulieu, M. (2009). Aligning competitive priorities in the supply chain: the role of interactions with suppliers. International Journal of Operations \& Production, 29(4), 322-340. https://doi.org/10.1108/01443570910945800

Vision 2030. (2017). Achieving Environmental Sustainability. Retrieved from http://vision2030.gov.sa/en/node/10

Wan Mahmood, M. N., Ab Rahman, K., Jusoff, A., Saptari, Z., Ebrahim, A. A., Mohamed Sultan, M. H., ... Jano, Z. (2013). Manufacturing Performance in Green Supply Chain Management. Special issue of Engineering and Technology, WASJ, 21, 76-84.

Wang, Y.-M., Wang, Y.-S., \& Yang, Y.-F. (2010). Understanding the determinants of rfid adoption in the manufacturing industry. Technol. Forecast Soc. Chang., 77, 803-815. https://doi.org/10.1016/j.techfore.2010.03.006

WCED-World Commission on Environment and Development. (1987). Our common future. Oxford University Press. Oxford, UK.

Wolf, C., \& Seuring, S. (2010). Environmental impacts as buying criteria for third-party logistical services. International Journal of Physical Distribution \& Logistics Management, 40(1/2), 84-102. https://doi.org/10.1108/09600031011020377

Wolf, J. (2011). Sustainable supply chain management integration: A qualitative analysis of the German manufacturing industry. J. Bus. Ethics, 102, 221-235. https://doi.org/10.1007/s10551-011-0806-0

York, K. M. (2010). Applied human resource management: Strategic issues and experiential exercises. Thousand Oaks, CA: Sage.

Yu Lin, C. (2007). Adoption of green supply in Taiwan logistic industry. Journal of management study, 90-98.

Yusup, M., Mahmood, W., Salleh, M., \& Ab Rahman, M. (2015). The implementation of cleanerer production practices from Malaysian manufacturers' perspectives. Journal of Cleanerer Production, 108.

Zhu, Q., \& Sarkis, J. (2007). The moderating effects of institutional pressures on emergent green supply chain practices and performance. International Journal of Production Research, 45(18), 4333-4355. https://doi.org/10.1080/00207540701440345

Zhu, K., \& Weyant, J. P. (2003). Strategic decisions of new technology adoption under asymmetric information: a game theoretic model. Decis. Sci., 34(4), 643-675. https://doi.org/10.1111/j.1540-5414.2003.02460.x

Zhu, K., Kraemer, K. L., \& Xu, S. (2003). E-business adoption by European firms: a cross-country assessment of the facilitators and inhibitors. European Journal of Information Systems, 12(4), 251-268. https://doi.org/10.1057/palgrave.ejis.3000475

Zhu, Q., Sarkis, J., \& Lai, K. (2007). Green Supply Management: Pressures, Practices, and Performance within the Chinese Automobile Industry. Journal of Cleaner Production, 15(11-12), 1041-1052. https://doi.org/10.1016/j.jclepro.2006.05.021

Zhu, Q., Sarkis, J., \& Lai, K.-H. (2008). Green supply chain management implications for "Closing the Loop." Transp. Res. Part E: Logistics. Transp. Rev., 44, 1-18. https://doi.org/10.1016/j.tre.2006.06.003

\section{Copyrights}

Copyright for this article is retained by the author(s), with first publication rights granted to the journal.

This is an open-access article distributed under the terms and conditions of the Creative Commons Attribution license (http://creativecommons.org/licenses/by/4.0/). 